\title{
Evde Bakım Birimince Takip Edilen Hastaların Bakımlarından Sorumlu Kişilerde Depresyon
}

$\underline{\text { Serkan TOKER }}^{1}, \underline{\text { Arzu AYRALER }}^{2}, \underline{\text { Rahime ÖZGÜR }}^{3}$

\begin{abstract}
$\ddot{\mathbf{O} z}$
Evde bakım hastalarının bakıcılarında en sık gözlenen ruhsal bozukluklardan biri de depresyondur. $\mathrm{Bu}$ çalışma, Evde bakım hastalarına bakım verenlerin depresyon sıklığını belirlemek ve sosyodemografik değişkenlerle depresyon sıklığı arasındaki ilişkiyi incelemek amacıyla yapılmıştır. 1 Nisan 2009- 1 Mayıs 2013 tarihleri arasında; Gazi Osman Paşa Taksim Eğitim ve Araştırma Hastanesi Evde sağlık polikliniğinden hizmet alan 230 hastanın 140 bakıcısına ulaşılmıştır. Sosyodemografik özelliklerin yer aldığı veri formu ile depresif belirti düzeyini değerlendirebilmek için Beck Depresyon Ölçeği kullanılmıştır. Bakım veren kişilerin yaş ortalaması 45,43 $\pm 12,62$ idi. Hastalara bakım veren kişileri Beck Depresyon ölçeği ile incelendiğinde; 4-60 arasında değişmekte olup, ortalaması $28,01 \pm 15,45$ 'dir ve $\% 72,1$ 'inde depresyon riskinin var olduğu görülmüştür. Kadın bakıcılarda depresyon riski erkeklere göre daha yüksektir. Bakım verenlerin bakım aktivitelerini yürütürken psikolojik, ekonomik ve aile içi ilişkilerde güçlük yaşadığı, günlük yaşam aktivitelerinin olumsuz etkilendiği ve dolayısıyla depresyon ve benzeri durumlarla yaşam kalitelerinin bozulduğu saptanmışır.
\end{abstract}

Anahtar Kelimeler: Evde sağlık, depresyon, hasta bakıcı, bakım veren, kadın, psikolojik
Yayın Bilgisi

Gönderi Tarihi: 07.11.2018

Kabul Tarihi: 02.04.2019

Online Yayın Tarihi: 31.12.2019

DOI: $10.26453 /$ otjhs. 479718

Sorumlu Yazar Serkan TOKER

Aile Hekimliği Uzmanı,

Fatih Aile Sağlığı Merkezi/ Kütahya.

Tel: 05302250770

Email: serkantoker@hotmail.com

\section{Depression in Persons Responsible for the Care of Patients Followed at Home Care}

$\underline{\text { Serkan TOKER }}^{1}, \underline{\text { Arzu AYRALER }}^{2}, \underline{\text { Rahime ÖZGÜR }}^{3}$

\begin{abstract}
Depression is one of the most frequently observed mentaldisorders in care givers of homecare patients. This study was conducted to determine the frequency of depressions of caregivers and to Investigate the relationship between sociodemographic variables and depression frequency. Between 1 April 2009 and 1 May 2013; there were 140 caregivers of 230 patients who received service from the Health Polyclinic at Gazi Osman Paşa Taksim Training and Research Hospital. Beck Depression Scale was used to evaluate the depressive symptom level with the data form including sociodemographic features. The mean age of the caregivers was $45.43 \pm 12.62$ years. When the caregivers of patients were examined with Beck Depression Scale; It is between 4-60, the average is $28.01 \pm 15.45$ and $72.1 \%$ of the risk of depression was seen. Female caregivers have a higher risk of depression than men. It was found that the caregivers had difficulty in psychological, economic and family relations while carrying out their care activities, the activities of daily living were negatively affected and therefore the quality of life was impaired with depression and similar situations.
\end{abstract}

Article Info

Received: 07.11.2018

Accepted: 02.04.2019

Online Published: 31.12 .2019

DOI: $10.26453 /$ otjhs. 479718

Corresponding Author Serkan TOKER

Aile Hekimliği Uzmanı,

Fatih Aile Sağlığı Merkezi/ Kütahya.

Tel: 05302250770

Email: serkantoker@hotmail.com

Keywords: Health at home, depression, caregiver, female, psychological

${ }^{1}$ Fatih Aile Sağlığı Merkezi/ Kütahya, Türkiye.

${ }^{2}$ Giresun Üniversitesi Tıp Fakültesi Aile Hekimliği ABD/Giresun, Türkiye.

${ }^{3}$ Taksim Eğitim ve Araştırma Hastanesi Dahiliye Uzmanlığı/ İstanbul ,Türkiye

\section{GíRiș}

Gelecek 20 yılda, dünya nüfusunun sağlık ihtiyaçlarında çarpıcı değişiklikler olacağı tahmin edilmektedir. Beklenen değişikliklerin en önemlilerinden birisi de kronik hastalıklar, psikolojik rahatsızliklar ve kazalara bağlı sakatlıklarda görülen artışlardır. Dolayısıyla, dünyanın her yerinde uzun süreli bakım ihtiyacında hızlı bir artış söz konusudur. ${ }^{1-2}$
Ailede sağlık problemleri dişında da stres yaratan birçok durum vardır. Maddi güçlükler, sevilen bir insandan ayrılma gibi durumlar strese neden olabilecek yaşam olaylarıdır. ${ }^{3-}$ ${ }^{4}$ Kişinin benlik saygısını ve bireysel bütünlüğünü tehdit eder. Her insanın olası stres verici olayları algılamasında bireysel farklılıklar vardır. $\mathrm{Bu}$ algılamayı etkileyen faktörler; bireyin yaşantıları sonucu elde ettiği 
deneyimleri, olaya ilişkin bilişsel değerlendirmeleri ve stres kaynağı karşısında birey için anlamlı sosyal destek sistemlerinin varlığı ve yeterliliğidir. ${ }^{5}$

Depresyon tipik olarak 6 olağan etkinliklerden ve daha önce kişiye zevk veren durumlardan eskisi gibi zevk alamama ve bunlara karşı ilginin kaybolmasıyla kendini gösteren, çökkünlük, karamsarlık anında keder ve elem duygularıyla seyreden depresif bir duygu durumu (disforik mood), Gerek mental gerekse fiziksel alanda enerji azlığı ile kendini gösteren psikomotor yavaşlama (psikomotor baskılanma), düşünce içeriği kısıtlılığı ile belirgin bilişsel yavaşlama (bilişsel baskılanma), kişinin işlevselliğinde azalma ile kendini gösteren bir hastalıktır.6-7

Araştırmamızın amacı bakım verenlerin depresyon sıklığını incelemek ve yapılmış diğer farklı çalışma sonuçlarıyla paralel olarak tartışmaktır.

\section{MATERYAL VE METOT}

Tanımlayıcı nitelikteki çalışmamız için 17.04.2013 tarihli ve 22 sayılı etik kurul onay1 alınarak 1 Nisan 2009- 1 Mayıs 2013 tarihleri arasında; Gazi Osman Paşa Taksim Eğitim ve Araştırma Hastanesi Evde sağlık polikliniğinden hizmet alan 230 hastanın 140 bakıcısına ulaşıldı ve 140 hasta yakınına kişisel veri formu yüz yüze uygulandı. Bakımdan sorumlu kişilerden en az altı aydır bakım veriyor olanlar ve 19 yaş üzerindeki kişiler çalışmaya dâhil edildi.
Araştırmada bilinçsiz nöroloji hastasına bakım veren hasta yakınlarının depresyon durumunu belirlemek amaciyla, 1961 yılında Beck tarafından geliştirilen ve Hisli tarafından uyarlanan Beck Depresyon Envanteri (BDE) kullanıldı. 21 maddeden oluşan ölçekte her madde, depresif belirtilerin derecesine göre azdan çoğa doğru sıralanmış $0-3$ arası puanlanan dört ifadeden oluşmaktadır. Ölçekten alınabilecek en yüksek puan 63 olup, yüksek puanlar, depresif belirtilerin fazla olduğunu göstermektedir. Depresyon için ölçek puanlarına göre 0-13 puan 'Depresyon Yok', 14-24 puan 'Orta Derecede Depresyon', 25 'ten büyük puanlar 'Ciddi Depresyon' olarak değerlendirildi. Beck Depresyon Envanteri için; 0 - 9 puan: Minimal depresif belirti, 10-16 puan: Hafif derecede depresif belirti, 17 - 24 puan: Orta derecede depresif belirti, 25 ve üzeri puan: Ciddi depresif belirti olarak belirtildi. ${ }^{8}$

Araştırmada yer alan evde bakım hastalarına bakım verenlere ilişkin bilgileri elde etmek üzere araştırmacı tarafından geliştirilen kişisel bilgi formu kullanılmıştır. $\mathrm{Bu}$ form; bakım veren refakatçiyi tanıtıcı olacak şekilde; yaş, cinsiyet, eğitim, medeni durum, maddi durum, etnik yapı, hastaya olan yakınlık derecesi, bakım verme süresi-sürekliliği gibi durumlar hakkında verileri elde etmeye yönelik sorulardan ve bakımı yapılan hastaların yatağa bağımlılıkları, idrar-gaita inkontinansı 
durumları, konuşkanlıkları ile ilgili bilgileri elde etmeye yönelik sorulardan oluşturuldu.

Kişisel bilgi formunda yaş Aralığı 19-39 yaş ile 40 yaş ve üzeri olarak iki grupta incelendi. Eğitim durumu aralığg üç grupta incelendi. İlk grup okur-yazar olmayan ve okuryazar olan, ikinci grup ilk ve ortaokul mezunu olan; üçüncü grup ise lise, üniversite ve üzeri okullardan mezun olan katılımciları içermektedir.

Katılımcılar arasında yüksek maddi durumlu refakatçi olmadığından, maddi durum aralığında yalnız orta ve düşük maddi duruma yer verildi. Düşük maddi durum olarak asgari ücret ve aylık 1000 TL altında kazanma durumu kıstas alındı. Evde bakım hastalarına bakım veren refakatçiler; ücret alma durumlarına göre ücretli; hastaların birinci derece yakınları olmalarının yanında, hastanın eşi olan ve eşi olmayan olmak üzere toplam üç farklı grupta incelendi. Bakım süreleri bir ay ve daha uzun süredir bakım verenler ve bir ayın altında bakım verenler olmak üzere iki başlıkta, bakım sıklığı da aralıklı bakım verenler ve sürekli bakım verenler olmak üzere farklı iki başlıkta incelendi. Bakıcılar etnik yapılarına göre, kırsal ve kentsel; medeni hallerine göre bekâr ve evli olarak iki başlıkta incelenmişlerdir.

Bakıcılar bakım verdikleri hastalar açısından; yatağa bağımlılık durumlarına göre; tam-kısmi bağımlı ve yataktan bağımsız olmak üzere üç grupta konuşkanlık durumlarına göre hiç konuşamayan ya da anlamsız sesler çıkaran ve iletişim kuramayan / yok denecek kadar az olan grup; anlamsız da olsa kurduğu cümleler/ kelimeler ile iletişim kurabilen, iletişimi sınırlı grup- ve anlamlı cümleler kurup konuşabilen iletişimi normal veya normale yakın grupolmak üzere üç grupta; idrar ve /veya gaita inkontinansı olmaları durumlarına göre de iki farkl1 grupta kategorize edildi.

Katılımcılara çalışma hakkında gerekli bilgi verilip, bilgilendirilmiș gönüllü olur formu okutuldu.

\section{Verilerin Toplanmast}

Araştırma verileri GOP Taksim EAH başhekimliğinden yazılı izin alındıktan sonra uygulanmıştır. Evde bakım polikliniğince takip edilen hastaların bakım vericilerinden sözlü izin alındıktan ve araștırmanın amacı açıklandıktan sonra bakım veren 140 hasta yakınına ev ziyaretleri esnasında veya telefon ile ulaşıldı her katılımcı ile yaklaşık 25-30 dakika görüşüldü. Okuma yazma bilmeyen katılımcılara her madde okundu ve kendilerine en uygun gelen cevabı sözlü olarak ifade edilen cevap forma kaydedildi.

\section{İstatiksel Analiz}

Araştırmada istatistiksel analizler için NCSS ( Number Cruncher Statistical System) 2007\&PASS (Power Analysis and Sample Size) 2008 Statistical Software ( Utah, USA) programı kullanıldı. Çalışma verileri değerlendirilirken tanımlayıcı istatistiksel değerlerinin (Ortalama, Standart sapma, 
medyan, s1klık, oran) yanı sira Beck puanlarının üç gruba göre karşılaştırmalarında One way Anova test ve farklılığa neden çıkan grubun tespitinde Tukey HDS test kullanıldı. Beck puanlarının sinıflanarak yapılan değerlendirmelerinde ise SPSS 20 programı Ki-Kare testi kullanıldı. Sonuçlar \%95'lik güven aralığında, anlamlılık $\mathrm{p}<0,05$ düzeyinde değerlendirildi.

\section{Araștırmanın Sınırlılıkları}

Araştırmaya yalnızca Taksim hastanesi evde sağlık polikliniğince 1 Nisan 2009 ve 1 Mayıs 2013 tarihleri arasında takip edilen hastaların 19 yaş ve üzerindeki en az altı aydır bakım verenler ile bu süreçte hastanın yanında bulunan birinci derece yakınlar dâhil edildi.

\section{BULGULAR}

Çalışma 01.04.2013-01.05.2013 tarihleri arasında GOP Taksim Eğitim ve Araştırma Hastanesi Aile Hekimliği Kliniğinde yapıldı. Evde Sağlık kapsamında Takip edilen hastalara bakım veren kişilerin demografik bulguları tablo 1'de gösterilmiştir.

Hastalara bakım veren kişilerin yaş dağılımı incelendiğinde; 22 ile 71 arasında değişmekte

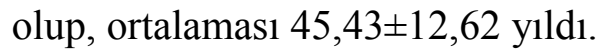

Eğitim durumlarına bakıldığında; \%18,6's1 $(n=26)$ okuryazar değil veya okuryazar, $\% 67,1^{\prime} i(n=94)$ ortaöğretim, \%14,3'ü $(n=20)$ lise, üniversite ve yüksek okul mezunudur. Hastalara bakım veren kişilerin \%31,4'ü $(n=44)$ hastanın eşi, \%60'1 $(n=84)$ akrabası, $\% 8,6$ 's1 $(\mathrm{n}=12)$ ücretli bakıcıdır ve \%77,9'u $(n=109)$ başka bir işte çalışmazken \%22,1'i $(\mathrm{n}=31)$ ise çalışmaktadır.

Çalışmaya aldığımız olguların \%29,3’ü $(n=41)$ bekâr, \%70,7’si (n=99) evlidir. Olguların kişisel gelirleri ve etnik yapıları incelendiğinde; \%43,6'sının $\quad(n=61)$ düşük gelire sahip olduğu ve kentsel kökenli olduğu, \%56,4'ünün $(\mathrm{n}=79)$ orta düzeyde gelire sahip olduğu ve kırsal kökenlidir.

Evde sağlık kapsamında takip edilen hastaların bilgilerinin dağılımı tablo 2' de gösterildi.

Evde sağlık kapsamında takip edilen hastaların bilgilerinin dağılımı tablo 2' de gösterilmiştir.

Evde sağlık kapsamında takip edilen hastaların durumları incelendiğinde; \%59,3'ü $\quad(n=83)$ idrar ve/veya gaita kaçırıyordu.

Kısmen yatağa bağımlı \%31,4 $(\mathrm{n}=44)$, yatağa bağımlı \%57,9 $(\mathrm{n}=81) \quad$ olgu saptanırken $\% 10,7$ 'si $(\mathrm{n}=15)$ ise yatağa bağımlı değildir. Hiç konuşamıyor ya da anlamsız sesler çıkarıyor ve iletişim yok yâda yok denecek kadar az \%19,3 (n=27) olgu görülürken, \%26,4'ü (n=37) anlamsız da olsa kurduğu cümleler/ kelimeler ile iletişim kurabiliyor ve iletişim sınırlı, \%54,3'ü $(\mathrm{n}=76)$ ise anlamlı konuşabiliyor, iletişim normal ya da normale yakın olarak saptanmıştır.

Evde sağlık kapsamında takip edilen hastaların klinik bulgularının dağılımı tablo 2'de gösterilmiştir

Hastalara bakım veren kişileri Beck Depresyon ölçeği ile incelendiğinde;4-60 arasında değişmekte olup, ortalaması 
$28,01 \pm 15,45^{\prime}$ dir ve $\% 72,1^{\prime}$ inde $\quad(n=101)$ depresyon riskinin var olduğu görülmüştür. Beck depresyon ölçeği puanları dağılımı tablo 3'de gösterildi.

Yaş gruplarına göre Beck depresyon varlığı 39 yaş üzerinde $\% 73,3$ olguda görülürken, $\% 70,4$ oranında ise 39 yaş altı olgu da görüldü. Öğrenim düzeyi, ekonomik durum, çalışma durumu ve etnik yapıya göre Beck Depresyon görülme oranları arasında istatistiksel olarak anlamlı farklılık saptanmamıştı $\quad(p>0,05)$. Medeni duruma göre de depresyon oranları arasında fark saptanmamış ancak evli olgularda depresyon oranının yüksekliği dikkat çekici düzeydedir. Bakım veren kişilerin demografik özelliklerine depresyon durumları dağılımı tablo 4'de gösterildi.

Cinsiyetlere göre depresyon görülme oranları arasında istatistiksel olarak anlamlı farklılık saptand $1(p<0,05)$. Kadın olgularda depresyon anlamlı düzeyde yüksek oranda saptand1. Cinsiyetlere göre Beck depresyon dağılımı şekil 1'de gösterildi.

Bakım veren kişilerde hastanın yatağa bağımlılık durumuna göre Beck Depresyon görülme puanları incelendiğinde aralarında istatistiksel olarak anlamlı farkl11ık saptand1 $(p<0,01)$. Yatağa bağımlı ve kısmen bağımlı olguların bakım vereninde bağımsız hareket eden olguların bakım verenlerine göre depresyon puanları anlamlı düzeyde yüksektir $(p<0,01)$. Kısmen bağımlı olanlarla tamamen bağımlı olan hastaların bakım verenlerinin depresyon puanları arasında anlamlı farklılık saptanmadı $(\mathrm{p}>0,05)$. Yatağa bağımlı olguların depresyon puanı 29,33 $\pm 14,54 ; \quad$ kismen bağımlıların $29,75 \pm 16,57$ ve bağımsızların ise $15,73 \pm 11,71$ 'idi.

Hastanın iletişim kurma durumuna göre bakım verende depresyon puanları arasında istatistiksel olarak anlamlı farklılık saptanmadı $(\mathrm{p}>0,05)$. Hiç konuşamayan ya da anlamsız sesler çıkaran iletişim kurulamayan hastalara bakım verenlerin Beck puanı ortalaması 24,19 $\pm 13,94$ iken, kısmen iletişim kuran hastalara bakım verenlerin puanı $29,24 \pm 15,57$ ve normal iletişim kuranların bakım verenlerinin puanı ise $28,76 \pm 15,88$ olarak saptandi.

Bakım veren kişilerin yakınlık durumuna göre Beck Depresyon puanları incelendiğinde aralarında istatistiksel olarak ileri düzeyde anlamlı farklılık saptand $1 \quad(p<0,01)$. Ücretli bakıcıların depresyon puanları eş ve akraba olanlardan ileri düzeyde anlamlı düşük olarak saptandı $(p<0,01)$. Eş bakıcıların puanları da akraba bakıcılardan anlamlı düzeyde düşük idi $(\mathrm{p}<0,05)$.

Hastaya bakım verme sıklığına göre depresyon görülme oranları arasında istatistiksel olarak anlamlı farklılık saptandı $(\mathrm{p}<0,01)$. Sürekli bakım veren olgularda depresyon anlamlı düzeyde yüksek oranda saptand1.

Hastaya bakım verme süresine göre depresyon görülme oranları arasında istatistiksel olarak anlamlı farklılık saptand $1(\mathrm{p}<0,01)$. Hastasına 
30 gün üzerinde bakım veren olgularda depresyon anlamlı düzeyde yüksek oranda saptand1.

Bakım veren kişilerin yakınlık durumuna göre Beck Depresyon puanları incelendiğinde aralarında istatistiksel olarak ileri düzeyde anlamlı farklılık saptand $1 \quad(p<0,01)$. Ücretli bakıcıların depresyon puanları eş ve akraba olanlardan ileri düzeyde anlamlı düşük olarak saptandı $(p<0,01)$. Eş bakıcıların puanları da akraba bakıcılardan anlamlı düzeyde düșük idi $(\mathrm{p}<0,05)$.

Hastanın idrar veya gaita kaçırma durumuna göre bakım verende depresyon görülme oranları arasında istatistiksel olarak anlamlı farkl1lık saptandı $(\mathrm{p}<0,01)$. İdrar veya Gaita kaçıran olguların bakım verenlerinde depresyon anlamlı düzeyde yüksek oranda saptanmıştır.

\section{TARTIŞMA VE SONUÇ}

Hastasına 30 gün üzerinde bakım veren olgularda depresyon anlamlı düzeyde yüksek oranda saptand $1 \quad(p<0,01)$.Birinci derecede bakım veren kişi, hastanın günlük yaşantısının merkezinde olduğundan çoğunlukla hastalıkla ilgili olarak hastanın sosyal ağıyla temas halindedir. Bakım sunma sorumlulukları arttıkça bakım sunma-bakım alma ilişkisi bakım verenin yaşamını sıkıntıya sokan, tek yönlü, bağımlı, yoğun ve uzun dönemli bir zorunluluğa dönüşsebilmektedir. Genellikle ailede bakım sunmanın kronik ve yoğun yapısı bakım verenlerin yaşamlarındaki (iş, aile hayatı, sosyal yaşam gibi) diğer taleplerden kaynaklanan anlaşmazlıklarla birleşince bakım veren yüküne yol açabilmektedir.

Literatürde "yük" bakım verenin üstlendiği bakımın ortaya çıkardığı ruhsal sıkıntı, bedensel sağlık sorunları, ekonomik sorunlar, sosyal sorunlar, aile ilişkilerinin bozulması ve kontrolün kendisinde olmadığ 1 duygusunu yasama gibi olumsuz objektif ve sübjektif sonuçlar şeklinde tanımlanmaktadır. ${ }^{9}$

Hasta bakımı sırasında ortaya çıkan ruhsal güçlükler; huzursuzluk, uykusuzluk, benlik saygisında azalma, depresyon, sosyal yalitım ve ilaç kullanımında artış şeklinde görülmektedir. Bakım veren hasta bakımına ilişkin duygularını baskılarsa stres, depresyon gibi durumların daha fazla ortaya çıkacağı, bu nedenle bakım sorunların tartışılması, bu sorunların çözülmeye çalışılmasının bakım vermeye ilişkin baskı, kaygı ve isteksizliği azaltmada önemli olduğu belirtilmektedir. ${ }^{10}$ Araştırmanın amacı doğrultusunda yapılan analiz sonucu, evde sağlık hastalarına bakım veren kişilerin BECK Skoru dağılımı incelendiğinde; 4-60 arasında değişmekte olup, ortalaması $28,01 \pm 15,45^{\prime}$ dir $\quad$ ve $\% 72,1$ 'inde $(\mathrm{n}=101)$ depresyon var olduğu görüldü.

Depresyon psikiyatrik hastalıklar arasında en s1k görülenlerden biridir. $\mathrm{ABD}$ 'de Epidemiologic Catchment Area (ECA) çalışmalarına göre majör depresyon sıklığı \%3-5,8iken hayat boyu risk; erkekler için \%312 kadınlar için \%10-26 olarak verilmektedir. 
Genel toplumda yaşam boyu prevalans \%15 kadardır. Türkiye Ruh Sağlığı Profili çalışmasında ise 12 aylık depresif nöbet yaygınlığı kadınlarda \%5,4 erkeklerde \% 2,3 tüm nüfusta $\% 4$ olarak verilmektedir. ${ }^{7}$

Robert Wood Johnson Vakfi'nın 2001 yılında yaptığı çalışmada, emosyonel rahatsızlıklarının yüksek oranda bulunduğu bakım vericilerin risk grubunda oldukları saptanmış ve depresyon oranlarının $\% 22$ civarında olduğu bulunmuştur. ${ }^{11}$ Mutschler; bakım vericilerin yaklaşık \%46-59'unun klinik düzeyde deprese olduğunu belirtmektedir. ${ }^{12}$

Literatürlerde sunulan birçok çalışmada, Alzheimer hastalarına bakım verenler arasında depresyon, anksiyete, yüksek tansiyon, mide ülseri ve öteki strese bağlı bozukluklar toplum genelinde olduğundan daha yüksek bulunmuştur. $^{13}$ Yine pek çok çalışmada demans hastalarına bakım verenlerde depresyon ve anksiyete düzeylerinin de artıı̆ını bildirilmektedir. Sales ${ }^{14}$ bakım verenlerde $\% 76$ oranında anksiyete ve $\% 42$ gibi yüksek bir oranda depresyon geliştiğini bildirmiştir. Çoğu çalışmada bakım verenler depresyon ölçekleri ile tarandığında, kesme noktası üzerinde puan almaktadırlar. ${ }^{15}$ Araştırmada, bakım verenlerin \%25'i $(n=35)$ erkek, \%75'i (n=105) kadındır. Kadın ve erkek grubunun depresyonlu olma düzeyleri arasında istatistiksel açıdan anlamlı bir fark bulunmuştur. $(\mathrm{p}<0,05) \quad$ Kadın olgularda depresyon anlamlı düzeyde yüksek oranda saptand1.

Kadınlarda depresyon görülmesi, erkeklerde depresyon görülmesinden yüksek idi. $\mathrm{Bu}$ sonuç, literatür sonuçlarıyla paralellik göstermekteydi. Kadın olmanın depresyonda önemli bir risk etkeni olduğu görüşü oldukça yaygındır. Biyolojik yapısı, ruhsal özellikleri, kişilik yapısı, sorunlarla başa çıkma tarzı, toplumsal ve kültürel konumu ile cinsel kimlik rolü kadını depresyona daha yatkın k1lmaktadır. ${ }^{16}$

Çalışmamızda hastaların bakım vericilerin erkeklerden daha çok kadınlar olduğu bulgulanmıştır. Sürekli bakım vererek sosyal izolasyonu yaşayan kadınların depresyon düzeylerinin olumsuz etkilendiği görülmektedir. Akdemir ve arkadaşları bakım verenlerin güçlüklerine ilişkin çalışmalarında, toplumumuzda ev hanımı olmanın doğal bakıcılığı beraberinde getirdiği ve bu nedenle kız çocukların ruhsal, sosyal ve ekonomik güçlükleri daha fazla yaşadıklarını bildirmektedir. Aynı zamanda çalışan kadınların, ișin yanı sıra bakım sorumluluğunu da üstlenmesiyle sosyal ve ruhsal zorlukları daha fazla yaşadıkları, emekli bakım veren grubun yaşlı ve kronik hastalıkları olmaları nedeniyle bakımda güçlük yaşadıkları bildirilmektedir. ${ }^{17}$

Toplumumuzda kadına verilen bakım verici rolü bizim çalışmamızda da görülmektedir. Aslında bakım denildiğinde, ülkemizde 
toplumsal rol olarak bakım işi ve sorumluluğu kadına atfedilmesi nedeniyle çocuk, hasta ve yaslı bakımında bakımı sağlayacak kişi olarak akla ilk kadın gelmektedir. Kadının eş, anne, bakım verme vb. toplumsal rolleri göz önüne alındığında, bakım yükü ve bakım stresi yaşaması ve bu rolleri yerine getirirken zorlanması kaçınılmazdır. Pek çok rolü olan kadın, kendi gereksinimlerinden feragat ederken karsı tarafa ilgi gösterme görevlerini de üstlenir. Sıklıkla kızgınlık, acı çekme, çaresizlik, pişmanlık gibi duyguları deneyimler ve bunları genellikle baskılar.

Hastalara bakım veren kişilerin yaş dağılımı incelendiğinde; 22 ile 71 arasında değişmekte olup, ortalaması 45,43 $\pm 12,62$ yıldır. Olguların \% 61,4'ü (n=86) 39 yaş üzeri, \%38,6's1 $(n=54)$ 39 yaş ve altında saptanmıştır. Yaş gruplarına göre Beck depresyon varlığı 39 yaş üzerinde $\% 73,3$ olguda görülürken, $\% 70,4$ oranında ise 39 yaş altı olgu da görülmüştür.

Evde sağlık hastalarına bakım verenlerin demografik özellikleri ile ilgili alınan bilgiler içinde yaşa göre depresyonlu olma durumunda istatistiksel olarak anlamlı bir fark saptanmaması literatür ile uyumluluk göstermemektedir. Bunun yanında, Aynalı'nın kanserli hasta yakınlarının hastanede kalma süreçleri ile ilgili yaptığı çalışmasında yaşlar arasında anlamlı bir fark bulgulamaması ile uyumluluk göstermektedir. ${ }^{18}$

Literatürde bakım verenin genç yaşta olması, bakım verenin yaşlı olmasına kıyasla sosyal desteğin daha az olması ile sonuçlanmakta ve bakım veren yükünün artmasıyla ilişkili görünmektedir. ${ }^{19}$ Kadınlar, özellikle daha genç yaşta olanlar, daha yaşlı erkeklere kıyasla bakım vermeyi daha negatif algılamakta, hastanın sağlık düzeyi ve bakım verme derecesi gibi faktörler kontrol edildiğinde bile daha fazla psikolojik zorluk yaşadıklarını bildirmektedirler. $^{20-21}$

Araştırmamızda bakım veren kişilerin yakınlık durumuna göre Beck Depresyon puanları incelendiğinde aralarında istatistiksel olarak ileri düzeyde anlamlı farklılık saptandı $(p<0,01)$. Ücretli bakıcıların depresyon puanları eş ve akraba olanlardan ileri düzeyde anlamlı düzeyde düşük olarak saptanmıştır $(p<0,01)$. Eş bakıcıların puanları da akraba grubu bakıcılardan anlamlı düzeyde düşüktür $(\mathrm{p}<0,05)$.

Literatürde eşlerde depresyon görülme sıklığının arttığını gösteren pek çok çalışma vardır. Mutschler araştırmasında, eşine bakan bakım vericilerin daha çok mental ve emosyonel gerginlik yaşadıklarını belirtmektedir. ${ }^{11}$ Ailelerini kurarken eşlerin birbirlerine verdikleri iyi ve kötü günde birlikte olma sözü toplum içinde de kabul görmektedir. Eşlerden birinin rahatsızlı̆̆ 1 diğerini oldukça olumsuz etkilemektedir. Rinaldi ve arkadaşlarının yaptığı çalışmada ise bakım verenin eşi ve ya kızı olması tükenmişlik ve stres riskini 6 kat artırdığını bulmuşlardır. ${ }^{7}$ Bakım verme süresi olarak 
bakıldığında ise; 29 gün ve altında bakım veren 17 kişiden 3ünde depresyon görülürken $(\% 17,6)$, bir ay ve üzerinde bakım veren 123 kişiden $\quad 98$ 'inde $\quad(\% 79,7)$ depresyon görülmektedir.

Hastaya bakım verme süresine göre depresyon görülme oranları arasında istatistiksel olarak ileri düzeyde anlamlı farklılık saptanmıştır $(p<0,001)$. Hastasına 30 gün üzerinde bakım veren olgularda depresyon anlamlı düzeyde yüksek oranda saptanmıştır. Çalışmamızda hasta yanında kalmanın süreklilik gösterip göstermemesine göre depresyon görülmesi arasında anlamlı fark görülmüştür. Hasta yanında sürekli kalan bakım vericilerde depresyon görülmesinin daha fazla olduğu saptanmıştır. Yapılan araştırmalardaki bulgular ile bizim bulgularımız paralellik göstermektedir. Mutschler çalışmasında bakım vericilerin farklı uğraşlar edinmelerinde ve günlük bakım hizmetlerinden yararlandıklarında daha az stres ve depresyon yaşadıklarını belirtmektedir. ${ }^{12}$ Aynalı, hasta yakınlarının sürekli hasta yanında bulunmaktan olumsuz etkilendiğini bulgulamıştır. $^{18}$

$\mathrm{Bu}$ araştırmanın sonucu olarak evde sağlık birimince takip edilen hastaların bakım verenlerinin çoğunluğunun 39 yaş üstü, kadın, ortaokul veya lise mezunu, evli, kırsal kökenli ve çalışmıyor olduğu saptanmıştır. Bakım veren kadınlarda; bakım veren eş harici 1 . Derece akrabalarda, idrar gaita inkontinansı olan, yatağa tam bağımlı hastaların bakım verenlerinde, 30 gün ve üzerinde ve sürekli bakım verenlerde anlamlı derecede depresyon saptanmiştır.

Gelişmekte olan ülkelerde, çoğunlukla, gereksinimi olan hastalara bakım; aileler ya da toplum tarafindan sağlanmaktadır. Aileler ve toplum hasta bireylerin koruma, bakım, destek ve tedavisinde anahtar rol oynamaktadir. Bakım verenler, hasta bireye yönelik psikolojik destek, iyi bir gözlem, fiziksel yardım, herhangi bir hastalık durumunda tedavi planının takibi, gerektiğinde yardım çağırmak gibi evde bakımda önemli birtakım görevleri yerine getirerek evde hasta bakımının temelini oluşturmaktadır. ${ }^{22}$

Ancak ülkemizde evde bakım hizmetleri yeni gelişmekte olduğundan bu önemli görevler yerine getirilirken hem bakım veren hem de bakımı alan aile bireyleri pek çok sorunla karşı karşıya kalmaktadır. Hastanın bakımından sorumlu olan kișinin; Hastanın yanında sürekli kalması, bakımdan tek başına sorumlu olması, çok genç olması ya da kendisinin yaşlı olması gibi çok fazla sorunu olduğunda bakım veren kişi ve aile üyelerinde kurum bakımına yönelme eğilimi artmaktadır. Evde sağlık hastalarına bakım veren bireylerde depresyon durumunu belirlemek amaciyla yaptığımız çalışma sonucunda, bakım verenlerin bakım aktivitelerini yürütürken psikolojik, ekonomik ve aile içi ilişkilerde güçlük yaşadığı, günlük yaşam aktivitelerinin olumsuz etkilendiği ve 
dolayısıyla depresyon ve benzeri durumlarla yaşam kalitelerinin bozulduğu saptanmıştır. Sonuçlar doğrultusunda; bakım verenlerin hastalarını gereksinim duydukça ve/ veya sürekli bırakabilecekleri kurumlar açılması, bakım verenlere yönelik danışmanlık ve eğitim hizmetlerinin yaygınlaştırılması, bakım verenlerin bakım nedeniyle yaşadıkları sorunların en aza indirilmesine yönelik olarak kurumsal uygulamaların başlatılması ve geliștirilmesine yönelik girişimlerin yapılması önerilmektedir.

\section{KAYNAKLAR}

1. Ülker ve ark. 1995; Evde Sağlık Bakım Hizmetlerinin Sunumuna İlişkin Temel ilkeler Toplantısının Grup Raporu .Şişli Etfal Hastanesi Hemşirelik Dergisi, İstanbul

2. WHO, 2000:1-14, 2000a HomeBasedLongTermCare, WHO Technical Report Series 898, Geneva 2000b Long Term Care Laws in Five Developed Countries: A Review. http://www.who.int/chp/knowledge/publica tions/ltc_laws_5developed_countries.pdf Erişim Tarihi: 01.05.2013 2006.

3. Kutlu Y. Sever A. Ruhsal bozukluğu olan bireylere sahip ailelerde hemşirelik süreci uygulaması. Hemşirelik Forumu Dergisi. 2002;5(1):53-55.

4. Özkan S. Zihinsel engelli ve normal çocuğa sahip annelerin algıladıkları sosyal destek ve depresyon düzeylerinin incelenmesi. Ankara Üniversitesi Eğitim Bilimleri Enstitüsü Yüksek Lisans Tezi.2002.
5. Demir B. Bilinçsiz Hasta Yakınlarının Depresyon Durumunun Belirlenmesi. Yüksek Lisans Tezi. Kocaeli Üniversitesi Sağlık Bilimleri Enstitüsü İç Hastalıkları Hemșireliği Anabilim Dalı,2006.

6. Kaplan Harold I, Sadock BJ. ComprehensiveTextbook of Psychiatry. 7th. Ed., Philadelphia, USA: Lippincott Williams and Wilkins, 2000.

7. Rinaldi P, Spazzafumo L, Mastriforti R. Study group on brain aging of the Italian society of gerontology and geriatrics. Predictors of high level of burden and distress in caregivers of demented patients: results of an Italian multicenter study. Int $\mathbf{J}$ Geriatr Psychiatry 2005; 20(2):168-74.

8. Hisli, N., (1988). Beck Depresyon Envanteri'nin geçerliliği üzerine bir çalışma.Psikoloji Dergisi. 6(22), s.118-126. Ve Hisli, N., (1989). Beck Depresyon Envanteri'nin üniversite öğrencileri için geçerliği, güvenirliği. Psikoloji Dergisi. 1988;7(23):3-13.

9. Mc Corkle R, Grant M, Frank S. M Baird S. CancerNursing: A Comprehensive Textbook, W.B. SaundersCompany, Philadelpia 1996.

10. İnci F. H, Erdem M. Bakım Verme Yükü Ölçeği'nin Türkçeye Uyarlanması, Geçerlilik ve Güvenilirliği. Yükseklisans Tezi, Pamukkale Üniversitesi Sağlık Bilimleri Enstitüsü, 2006. 
11. Dellasega C. Haagen, B. Aifferent kind of caregiving support group. Therapeutic writing was used to decrease stres and help group member scope. Journal of Psychosocial Nursing. 2004;8(42):47-54.

12. Mutschler P. Factsheet: Womenand Caregiving: FactsandFigures. Family Caregiver Alliance.2003.

13. Yilmaz A, Turan E. Alzheimer hastalarına bakım verenlerde tükenmişlik, tükenmişliğe neden olan faktörler ve baş etme yolları. Türkiye Klinikleri J Med Sci. 2007;27:445454 .

14. Brodaty H. Alzheimer Hastalığında İlaç Tedavisi ve Aileler. Alzheimer Hastalığının Farmakoterapisi. Ankara, Yelkovan Yayıncılık, 2000.

15. Sales E. FamilyBurdenandQuality of Life. Qual Life Res. 2003;2(1):33-41.

16. Sörensen S, Duberstein P, Gill D, Pinquart M. Dementiacare: menta health effects, intervention strategies, and clinical implications.LancetNeurol. 006;5(11):96173.

17. Akdemir N, Yurtsever S, Özer Z. Evde Bakım Gereksinimi Olan Hastalara Bakım Verenlerin Yaşadıkları Güçlüklerin Belirlenmesi. Mersin Üniversitesi T1p Fakültesi Dergisi. 2004;5(3):272-281.

18. Aynalı F.Girtlak Kanserli Hasta Yakınlarının Hastanede Kalma Sürecinde Yaşadıkları Sorunlar, Durumluluk Kaygı Düzeyleri ve Tibbi Sosyal Hizmet
Müdahalesi. Yüksek Lisans Tezi. Hacettepe Üniversitesi Sosyal Bilimler Enstitüsü. 2002.

19. Allen SM, Goldscheider F, Ciambrone DA. Genderroles, maritalintimacy, andnomination of spouse as primarycare giver. Gerontologist. 1999;39:150-158.

20. Daly BJ, Douglas S, Lipson A, Foley H. Needs of oldercaregivers of patientswith advancedcancer. J Am Geriatr Soc. 2009;57(2):S293-295.

21. Biegel DE,Millligan SE, Putham PL, Song L. Predictors of burden among lower socioeconomic status caregivers of Persons with chronic mental illness. Community Ment Health J. 1994;30:473-494.

22. Geriaco, AJ. Physicians guide to managing home care of older patients. Geriatrics. 1991;46:5, 49-55. 
Tablo 1. Evde Sağlık Kapsamında Takip Edilen Hastalara Bakım Veren Kişilerin Demografik Bilgilerinin Dağılımı.

\begin{tabular}{|c|c|c|c|}
\hline & & Ort \pm SD & Min-Max \\
\hline \multirow[t]{2}{*}{ Yaş (yıl) } & & $45,43 \pm 12,62$ & $22-71$ \\
\hline & & $\mathbf{n}$ & $\%$ \\
\hline \multirow[t]{2}{*}{ Yaş Grup } & $>39$ yaş & 86 & 61,4 \\
\hline & $\leq 39$ yaş & 54 & 38,6 \\
\hline \multirow[t]{2}{*}{ Cinsiyet } & Erkek & 35 & 25,0 \\
\hline & Kadın & 105 & 75,0 \\
\hline \multirow[t]{3}{*}{ Öğrenim Düzeyi } & Düşük & 26 & 18,6 \\
\hline & Orta & 94 & 67,1 \\
\hline & Yüksek & 20 & 14,3 \\
\hline \multirow[t]{2}{*}{ Medeni Durum } & Bekar & 41 & 29,3 \\
\hline & Evli & 99 & 70,7 \\
\hline \multirow[t]{2}{*}{ Ekonomik Durum } & $<1000 \mathrm{TL}$ & 61 & 43,6 \\
\hline & $\geq 1000 \mathrm{TL}$ & 79 & 56,4 \\
\hline \multirow[t]{2}{*}{ Etnik Yapı } & Kentsel & 61 & 43,6 \\
\hline & Kirsal & 79 & 56,4 \\
\hline \multirow[t]{3}{*}{ Bakıcının Yakınlık Durumu } & Eş & 44 & 31,4 \\
\hline & Akraba & 84 & 60,0 \\
\hline & Ücretli Bakıcı & 12 & 8,6 \\
\hline \multirow[t]{2}{*}{ Çalışma Durumu } & Çalışmıyor & 109 & 77,9 \\
\hline & Çalışıyor & 31 & 22,1 \\
\hline
\end{tabular}


Tablo 2. Evde Sağlık Kapsamında Takip Edilen Hastaların Klinik Durumlarının Dağılımı.

\begin{tabular}{llll}
\hline & & $\mathbf{n}$ & $\%$ \\
\hline İdrar, Gaita Kaçırma Durumu & Kaçırmıyor & 57 & 40,7 \\
& Kaçırıyor & 83 & 59,3 \\
Yatağa Bağımııık & Bağımıı & 81 & 57,9 \\
& Kısmi & 44 & 31,4 \\
\multirow{2}{*}{ İletiş̧im Kurma Durumu } & Bağımsız & 15 & 10,7 \\
& Suskun & 27 & 19,3 \\
\multirow{3}{*}{ Bakım Sıklığı } & Orta & 37 & 26,4 \\
& Konuşkan & 76 & 54,3 \\
Bakım Süresi & Aralıkıı & 29 & 20,7 \\
& Sürekli & 111 & 79,3 \\
& $\mathbf{1 - 2 9}$ gün & 123 & 87,9 \\
& $\geq \mathbf{3 0}$ gün & 17 & 12,1 \\
\hline
\end{tabular}


Tablo 3. Beck Depresyon Ölçeği Puanları Dağılımı.

\begin{tabular}{llll}
\hline \multirow{2}{*}{ BECK Skoru } & & Ort \pm SD & Min-Max \\
& & $28,01 \pm 15,45$ & $4-60$ \\
Depresyon Varlığı & $\mathbf{n}$ & $\boldsymbol{\%}$ \\
\cline { 3 - 4 } & Yok & 39 & 27,9 \\
& Var & 101 & 72,1 \\
\hline
\end{tabular}


Tablo 4. Bakım Veren Kişilerin Demografik Özelliklerine Göre Beck Depresyon Durumlarının Dağılımı.

\begin{tabular}{|c|c|c|c|c|c|}
\hline & & \multirow{2}{*}{$\begin{array}{l}\text { BECK Depresyon } \\
\text { puanı }\end{array}$} & \multicolumn{2}{|c|}{ BECK Depresyon } & \multirow[t]{3}{*}{$p$} \\
\hline & & & Yok & Var & \\
\hline & & Ort \pm SD & n (\%) & n (\%) & \\
\hline \multirow[t]{2}{*}{ Yaş Grup } & $>39$ yaş & $26,55 \pm 14,31$ & $23(26,7)$ & $63(73,3)$ & \multirow[t]{2}{*}{0,711} \\
\hline & $\leq 39$ yaş & $30,33 \pm 16,99$ & $16(29,6)$ & $38(70,4)$ & \\
\hline \multirow[t]{2}{*}{ Cinsiyet } & Erkek & $24,40 \pm 16,37$ & $15(42,9)$ & $20(57,1)$ & \multirow[t]{2}{*}{$0,022 *$} \\
\hline & Kadın & $29,21 \pm 15,02$ & $24(22,9)$ & $81(77,1)$ & \\
\hline \multirow[t]{3}{*}{ º̈ğrenim Düzeyi } & Düşük & $28,40 \pm 15,64$ & $9(34,6)$ & $17(65,4)$ & \multirow[t]{3}{*}{0,547} \\
\hline & Orta & $29,50 \pm 17,74$ & $26(27,7)$ & $68(72,3)$ & \\
\hline & Yüksek & $24,30 \pm 10,75$ & $4(20,0)$ & $16(80,0)$ & \\
\hline \multirow[t]{2}{*}{ Ekonomik Durum } & $<1000 \mathrm{TL}$ & $27,15 \pm 15,31$ & $18(29,5)$ & $43(70,5)$ & \multirow[t]{2}{*}{0,702} \\
\hline & $\geq 1000 \mathrm{TL}$ & $28,67 \pm 15,62$ & $21(26,6)$ & $58(73,4)$ & \\
\hline \multirow[t]{2}{*}{ Medeni Durum } & Bekar & $27,59 \pm 16,66$ & $16(39,0)$ & $25(61,0)$ & \multirow[t]{2}{*}{0,058} \\
\hline & Evli & $28,18 \pm 15,01$ & $23(23,2)$ & $76(76,8)$ & \\
\hline \multirow[t]{2}{*}{ Çalışma Durumu } & Çalışmıyor & $28,00 \pm 15,57$ & $31(28,4)$ & $78(71,6)$ & \multirow[t]{2}{*}{0,773} \\
\hline & Çalışıyor & $28,03 \pm 15,27$ & $8(25,8)$ & $23(74,2)$ & \\
\hline \multirow[t]{2}{*}{ Etnik yapı } & Kentsel & $26,62 \pm 15,53$ & $19(31,1)$ & $42(68,9)$ & \multirow[t]{2}{*}{0,445} \\
\hline & Kirsal & $29,08 \pm 15,40$ & $20(25,3)$ & $59(74,7)$ & \\
\hline
\end{tabular}

Ki kare test; ${ }^{1}$ Oneway Anova Test; ${ }^{*} p<0,05$ 


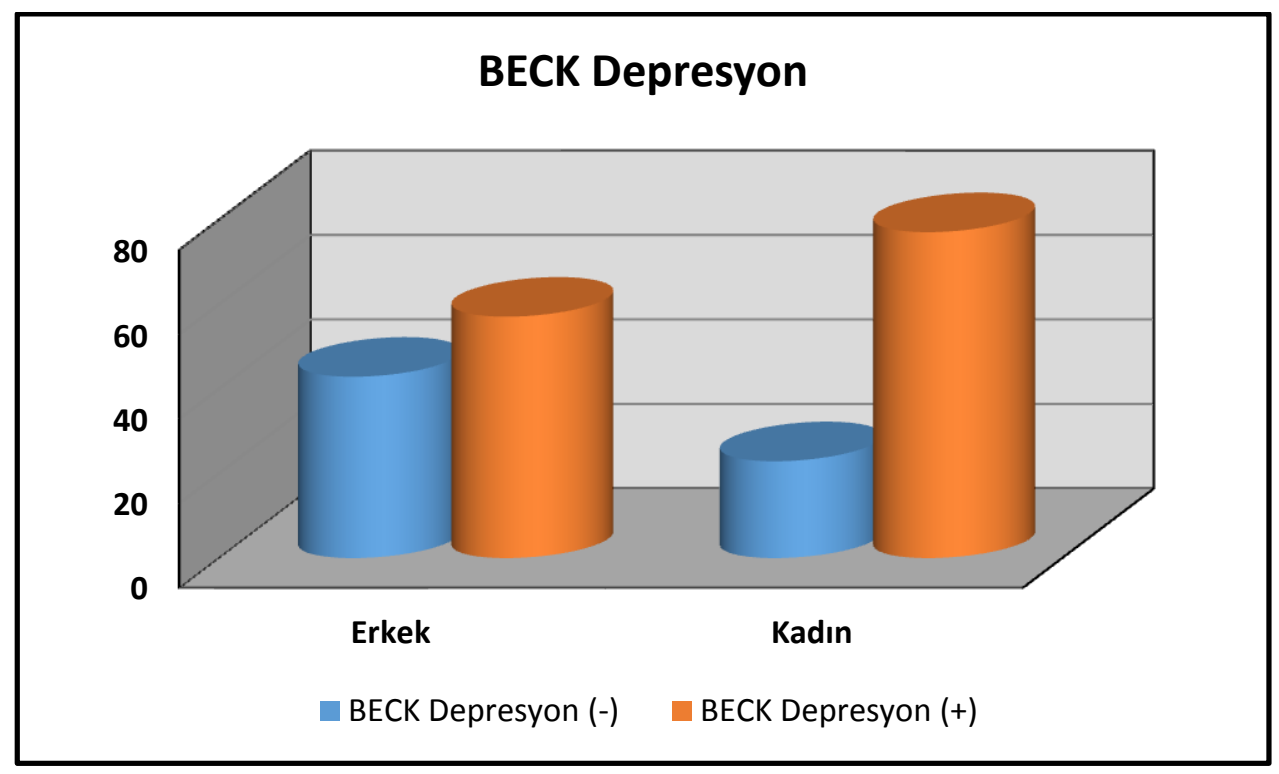

Şekil 1. Cinsiyetlere Göre Beck Depresyon Dağılımı. 